\title{
BIOPSYCHOSOCIAL DETERMINANTS OF PREECLAMPSIA IN KEDIRI, EAST JAVA
}

\author{
Katmini $^{1)}$, Febrina Dwi Nurcahyanti²), Astri Yunita3) \\ 1)Study Program in Nursing, School of Sciences Bhakti Mulia, Kediri, East Java \\ ${ }^{2,3)}$ Diploma Program in Midwifery, School of Sciences Bhakti Mulia, Kediri, East Java
}

\begin{abstract}
Background: Preeclampsia has remained a significant public health threat in both developed and developing countries contributing to maternal and perinatal morbidity and mortality globally. This study aimed to examine the biopsychosocial determinants of preeclampsia in Kediri, East Java.

Subjects and Method: This was a case control study conducted in Kediri, East Java. A sample of 100 pregnant mothers was selected for this study by fixed disease sampling, consisting of 25 pregnant mothers with preeclampsia and 75 without preeclampsia. The dependent variable was preeclampsia. The independent variables were maternal age, parity, Body Mass Index (BMI), perceived susceptibility, and perceived severity. The data were collected by questionnaire. The data were analyzed by a multiple logistic regression.

Results: Maternal age $<20$ years $(O R=1.75 ; p=0.023)$, nulliparous $(O R=1.56 ; p=$ $0.045), \mathrm{BMI} \geq 25(\mathrm{OR}=2.75 ; \mathrm{p}=0.037)$, low perceived susceptibility $(\mathrm{OR}=2.22 ; \mathrm{p}=$ $0.034)$, low perceived severity $(\mathrm{OR}=2.61 ; \mathrm{p}=0.048)$ were associated with an increased risk of preeclampsia.

Conclusion: Maternal age $<20$ years, nulliparous, BMI $\geq 25$, low perceived susceptibility, low perceived severity, are associated with an increased risk of preeclampsia.
\end{abstract}

Keywords: preeclampsia, maternal age, parity, body mass index, perceived susceptibility, perceived severity.

\section{Correspondence:}

Katmini. Study Program in Nursing, School of Sciences Bhakti Mulia, Kediri, East Java. Email: katminitini@gmail.com. Mobile: 082334662921. 